\title{
The effect of thermal, chlorine and ozone treatments on survival of Escherichia coli and Salmonella spp. in açai berries
}

\author{
Valeria Saldanha Bezerra ${ }^{1,4 *}$, Eduardo H. M. Walter ${ }^{2}$, Otniel Freitas-Silva ${ }^{2}$, \\ Izabela Alves Gomes ${ }^{3}$, Leandro Fernandes Damasceno ${ }^{4}$, Ivan Alcântara ${ }^{2}$, \\ Lourdes Maria Correa Cabral ${ }^{2}$ \\ ${ }^{\text {I}}$ (PPGCAL/Institute of Chemistry, Federal University of Rio de Janeiro. Av Athos da Silveira Ramos, 149 Bloco \\ A - $5^{\circ}$ andar, Cidade Universitária, CEP 21941-909, Rio de Janeiro, Brazil) \\ ${ }_{2}^{2}$ (Embrapa Agroindústria de Alimentos, Av. das Américas, 29501 - CEP 23020-470, Rio de Janeiro, Brazil) \\ ${ }_{3}^{3}$ (UNIRIO-Department of Food Technology, Nutrition School, Food and Nutrition Postgraduate Program \\ (PPGAN), Av. Pasteur, 296, CEP 22290-240, Rio de Janeiro, Brazil) \\ ${ }^{4}$ (Embrapa Amapá, Rodovia Juscelino Kubitscheck, 2.600 - Macapá, CEP 68903-419, Brazil) \\ *Corresponding authors: valeria.bezerra@embrapa.br,otniel.freitas@embrapa.br
}

\begin{abstract}
Açai berries (Euterpe oleracea Mart.) have a high natural microbial load that can compromise the quality of their products. In this study, test microorganisms were inoculated on raw açai berries in drip trials, with five strains of Salmonella spp. and E. coli, separately. Açai berries sanitizing processes were: $i)$ chlorination with $200 \mathrm{mg} . \mathrm{L}^{-1}$ for a period of $15 \mathrm{~min}$; ii) blanching at $80{ }^{\circ} \mathrm{C}$ for $10 \mathrm{~s}$ (regional legislation); iii) blanching at $90^{\circ} \mathrm{C}$ for $10 \mathrm{~s}$; iv) aqueous ozonation at $4 \mathrm{mg} . \mathrm{L}^{-1}$ for $5 \mathrm{~min}$; and v) washing with distilled water for 15 min as control treatment. Thermal treatment at $90{ }^{\circ} \mathrm{C} 10 \mathrm{~s}$ achieved the highest efficiency in reducing counts of E.coli (3.0 $\left.\pm 0.8 \log C F U . m L^{-1}\right)$. In Salmonella spp., all sanitizing treatments were similar and better than simple washing with water. Thus, blanching of açai berries at $90{ }^{\circ} \mathrm{C} 10 \mathrm{~s}$, with immediate cooling with chlorinated water $\left(50 \mathrm{mg} . \mathrm{L}^{-1}\right)$, is an alternative process for sanitization for açai berries, considering the application of good manufacturing practices.
\end{abstract}

Keywords - Bacteria, blanching, contamination, Euterpe oleracea; ozonation; thermal processing

\section{INTRODUCTION}

Açai (Euterpe oleracea Mart.) is a native palm tree of the Amazon rainforest that produces edible berries widely consumed as fresh beverages and frozen desserts in Brazil. It is also exported to many countries, mainly as pasteurized pulp. It is considered a functional and energy food, due to its high antioxidant capacity and potential health benefits, besides high nutritional value [1]. On the other hand, açai berries are typically highly contaminated in microbiological terms. The berries as well as other materials come from the field with initial microbiological contamination and this can increase during the chain until industrial processing into pulp.

The main source of açai berries contamination is water, since more than $50 \%$ of the municipalities located in the Brazilian Amazon do not use chlorinated water [2]. Raw berries traded for beverage processing can present fecal coliform concentrations $>3.0 \mathrm{log} . \mathrm{g}^{-1}$ dry matter, $7.0 \mathrm{log} . \mathrm{g}^{-1}$ dry matter of mesophilic bacteria and $5.2 \mathrm{log} \cdot \mathrm{g}^{-1}$ dry matter of molds and yeasts [3]. Without thermal treatment, mesophilic bacteria are also usually found in greater numbers in manually processed beverages than the limits established by current Brazilian regulations. In one study, a load of mesophilic bacterial contamination was observed of around $9.5 \mathrm{log}$ CFU. $\mathrm{kg}^{-1}$ berry [4]. There are also many reports of Escherichia coli and Salmonella spp. in açai berries, pulp and beverages [3].The regulations establish some procedures for processors, mainly blanching treatment of açai berries at $80{ }^{\circ} \mathrm{C}$ for $10 \mathrm{~s}$ [5], to deactivate Trypanosoma cruzi, the causative agent of Chagas disease [6]. Blanching for less than $10 \mathrm{~s}$ does not change the sensorial attributes of the beverage [7] and can be considered an efficient, easy and cheap process. In the case of cabbage, blanching in boiling water for 4 min produced a reduction of $3.8 \log$ CFU.cm ${ }^{2}$ in Salmonella spp. attached to the surface leaves [8].

Sodium hypochlorite is the most widely used chemical sanitizer of fresh produce, despite growing environmental and health concerns [9]. The recommendation of active chlorine concentrations for sanitizing fresh products is in the range of 50-200 mg.. $\mathrm{L}^{-1}$, with a contact time from 15 to $30 \mathrm{~min}$ [10]. The efficiency of chlorination can be influenced by organic matter present in water, as well as insufficient cooling, exposure to air or light, or a combination of these three factors [11]. Ozone $\left(\mathrm{O}_{3}\right)$ is one of the most powerful oxidizing agents $(2.07 \mathrm{mV})$, effective for inactivation of Gram-negative and Gram-positive bacteria, viruses and yeasts, including sporulated forms [12], and protozoan cysts [13]. Studies have shown that treatment with ozonated water extends the shelf life of various food products, increasing quality and food safety [14; 15]. Despite ozone's rapid 
decomposition in water, its antimicrobial action can be very effective for surface decontamination of fruits and vegetables [12].

This work aimed to study the effectiveness of decontamination methods of açai berries, by reducing the microbial load of Salmonella spp. and E. coli, through thermal (blanching) and non-thermal (chlorination and ozonation) processing.

\subsection{Açai berries}

\section{MATERIAL AND METHODS}

Açai berries (Euterpe oleracea Mart.) were collected from a stand of trees in Mazagão, Amapá state (Brazil). Açai berries were vacuum-packed (Tecmaq TM-250, Brazil) and refrigerated at $8{ }^{\circ} \mathrm{C} \pm 2$. They were weighed and washed three times in $200 \mathrm{~mL}$ of tap water to reduce the natural contamination.

Preliminary microbiological counts of the açai berries was performed, with 15 intact raw berries (approximately $20 \mathrm{~g}$ ), analyzed in the three repetitions.

2.2 Test microorganisms

The microorganisms tested were a pool of five strains each of Escherichia coli (ATCC 8739, ATCC 10799, ATCC 11229, ATCC 25922 and ATCC 43893) and Salmonella spp. (S. Choleraesuis ATCC 10708, S. Enteritidis ATCC 13076, S. Typhimurium ATCC 13311, S. Typhimurium ATCC 14028 and S. Brazil). The cultures were maintained in Tryptic Soy Agar (TSA) at $8 \pm 2{ }^{\circ} \mathrm{C}$. All strains of each test organism were evaluated in relation to the antagonistic effect on the ability to inhibit the growth of other strains [16].

\subsection{Inoculum preparation}

The inocula of the microorganisms were prepared from stock cultures [17]. The activated strains of each test microorganism were placed in $25-\mathrm{mL}$ tubes and centrifuged $(2,000 \mathrm{~g}, 15 \mathrm{~min}$, room temperature) three times. The supernatant was removed and the pellets were washed with $10 \mathrm{~mL}$ of $0.1 \%$ peptone water. The resulting cell masses were resuspended in $10 \mathrm{~mL}$ of $0.1 \%$ peptone water. Drops of $0.1 \mathrm{~mL}$ of each inoculum, in a total $1.0 \mathrm{~mL}$, were applied on the surface of açai berries, which were kept in a laminar flow cabinet for $30 \mathrm{~min}$ to dry the inoculum.

\subsection{Treatments}

Two assays were performed separately. In the first assay, açai berries were subjected to thermal (blanching) and chemical (chlorination and ozonation) treatments separately (Figure 1). In the second assay, açai berries were blanched at $90{ }^{\circ} \mathrm{C}$ and cooled with different aqueous sources (Figure 1). The ratio between the sample mass and the volume of water used in all test solutions for açai berries treatment was $40 \mathrm{~g} . \mathrm{L}^{-1}$ (12). The recovered microbial enumeration from berries of two assays was performed before decontamination treatments $\left(\mathrm{N}_{0}\right)$.

2.4.1 Thermal and chemical treatments

All treatments were conducted according to Figure 1. Inoculated berries immersed in distilled water at room temperature for $15 \mathrm{~min}$ and then drained represented the control treatment.

\subsubsection{Chlorination}

Inoculated açai berries were immersed in $500 \mathrm{~mL}$ of a $200 \mathrm{mg} \cdot \mathrm{L}^{-1}$ chlorinated water solution for $15 \mathrm{~min}$, using a commercial chlorine solution containing 2.0 to $2.5 \mathrm{wt}$ of available chlorine, after which berries were drained. The initial and final residual chlorine concentrations were measured by the DPD colorimetric method [18].

\subsubsection{Ozonation}

Açai berries were immersed in $500 \mathrm{~mL}$ of aqueous solution that had been previously ozonated for 5 min using an ozonator (Ozone \& Life 3.0 RM, Brazil) by the corona discharge method (Figure 2). The ozone was dissolved in water through a porous gas diffuser stone. The concentration of $4 \mathrm{mg} . \mathrm{L}^{-1}$ was monitored by an ozone analyzer (CHEMetrics I-2019 SAM, Brazil) with a photometric analytical kit (CHEMetrics K-7423) where initial and final concentrations of $\mathrm{O}_{3}$ were measured. After chlorination and ozonation treatments, a solution of $0.066 \mathrm{~mL}$ of $10 \%$ sodium thiosulfate (Synth) was added for ozone neutralization.

\subsubsection{Blanching}

Hot water was applied in two treatments: immersion of açai berries in $500 \mathrm{~mL}$ of water at $80{ }^{\circ} \mathrm{C}$ for $10 \mathrm{~s}$, as determined by local regulation [5] and in $500 \mathrm{~mL}$ of water at $90{ }^{\circ} \mathrm{C}$ for $10 \mathrm{~s}$. Açai berries were drained and cooled in $500 \mathrm{~mL}$ of $50 \mathrm{mg} . \mathrm{L}^{-1}$ chlorinated water at room temperature for $2 \mathrm{~min}$.

\subsubsection{Combining thermal treatment (blanching $90^{\circ} \mathrm{C}$ ) and cooling}


Açai berries were immersed in $500 \mathrm{~mL}$ of hot water at $90{ }^{\circ} \mathrm{C}$ for $10 \mathrm{~s}$ and then water from various sources was used for cooling. The control treatment was blanching at $90{ }^{\circ} \mathrm{C}$ and cooling in tap water at room temperature for 2 min, followed by draining

\subsubsection{Combining blanching with chlorination}

Açai berries blanched at $90{ }^{\circ} \mathrm{C}$ for $10 \mathrm{~s}$ were cooled in $500 \mathrm{~mL}$ of chlorinated water at concentration of $50 \mathrm{mg} . \mathrm{L}$

${ }^{1}$ or $200 \mathrm{mg} . \mathrm{L}^{-1}$ for $2 \mathrm{~min}$, using a commercial chlorine solution containing 2.0 to $2.5 \mathrm{wt}$ of available chlorine, after which berries were drained.

The initial and final residual chlorine concentrations were measured by the DPD colorimetric method [18].

\subsubsection{Combining blanching with ozonation}

Açai berries blanched at $90{ }^{\circ} \mathrm{C}$ for $10 \mathrm{~s}$ were cooled in $500 \mathrm{~mL}$ of ozonated water $\left(4 \mathrm{mg} . \mathrm{L}^{-1}\right.$ or $\left.5 \mathrm{mg} . \mathrm{L}^{-1}\right)$ for 2 min, separately. The water was previously ozonated for 5 min according to 2.4.1.2.

\subsection{Microbiological analysis}

The concentrations of the suspensions $\left(\mathrm{CFU} \cdot \mathrm{mL}^{-1}\right)$ of each strain and pool of five strains of Salmonella spp. and E. coli were determined by serial dilution (1:10) in $1.0 \mathrm{~mL}$ aliquots of $0.1 \%$ peptone water, followed by surface plating $(0.1 \mathrm{~mL}$, in duplicate) in different culture media. For enumeration of $E$. coli, we used eosin methylene blue (EMB) agar (Acumedia), while for Salmonella spp., we used xylose lysine deoxycholate agar (XLD) (Difco). Three isolated colonies of E. coli were subjected to biochemical confirmation by applying indole production, methyl red test, Voges-Proskauer reaction and citrate utilization (IMViC tests). In the recovery of test microorganisms on the açai berries processed by different treatments in both assays, it was utilized the proportional volume of water used to make thin acai beverages (14 $\mathrm{kg}$ açai berries: $4 \mathrm{~L}$ water) in processing. Açai berries were rubbed one by one on the outer layer for $1 \mathrm{~min}$, to avoid removal of pulp. Then the berry was revolved for 30 seconds to homogenize the suspension. Aliquots $(1 \mathrm{~mL})$ of the resulting recovered suspension were serially diluted in $0.1 \%$ peptone water. The surface plating $(0.1$ $\mathrm{mL}$ ) was performed in duplicate suspensions, and the counts expressed in CFU. $\mathrm{mL}^{-1}$.

\subsection{Statistical analysis}

The experiment consisted of two assays involving decontamination of açai berries inoculated with Salmonella spp. and E. coli. The experimental design was completely randomized, where each test was done in three replicates. The enumeration of microbial cells was expressed in $\log$ of 10 cycles. The treatments were assessed by calculating the microbial reduction $\left(\log \mathrm{N}_{0}-\log \mathrm{N}\right)$, where $\mathrm{N}_{0}$ is recovered microbial enumeration of the sample before decontamination treatments and $\mathrm{N}$ is the recovered microbial load after decontamination. Data were analyzed using the Statistica software (version 8.0, Stat Soft Inc., Tulsa, USA) for analysis of variance (ANOVA). The comparison of mean values of the parameters was performed by the Tukey test at 5\% significance level.

\section{RESULTS AND DISCUSSION}

The preliminary trials of untreated acai berries presented a total of aerobic count in the range of $8.6 \times 10^{4}$ to 1.9 x $10^{6}$ CFU.mL ${ }^{-1}$. Cross-inhibition tests showed no growth inhibition zone among all test microorganism strains evaluated. Thus, the mixing of strains that compose the respective inoculants of each test microorganism presented no problem of interaction of strains. The Salmonella spp. and E. coli inoculum concentrations of two assays were about 9-10 $\log$ CFU.mL ${ }^{-1}$ (Table 1). After applying the inoculum $(1.0 \mathrm{~mL})$ containing the test microorganisms on the surface of the berries and subsequent drying, the recovery was about $8.2 \log$ CFU.mL ${ }^{-}$ ${ }^{1}$ for Salmonella spp. and E. coli (Table 1). The Salmonella spp. recovery $\left(8.2 \log\right.$ CFU.mL ${ }^{-1}$ ) after inoculation of berries by drip was similar to that observed in pecans recovery $\left(7.0 \mathrm{log} . \mathrm{g}^{-1}\right)$ after inoculation of nutmeats and unshelled nuts for $1 \mathrm{~h}$ by immersion in a suspension of Salmonella spp. (8.7 $\log$ CFU.mL ${ }^{-1}$ ) [19]. The recovery values of Salmonella spp. (Table 1) were slightly lower than the number of mesophilic bacteria found naturally in açai berries during the off-season period (9.1 to $9.5 \log$ CFU.g ${ }^{-1}$ dry matter), but higher than during the harvest period (6.6 log CFU.g $\mathrm{g}^{-1}$ dry matter) [19]. This might indicate that the recovery test found contamination by mesophilic bacteria similar to that observed naturally on açai berries throughout the year. The recovery rate of Salmonella spp. and E. coli from açai berries was higher than that found in whole tomatoes and green onions $\left(6.74 \log C F U . m l . g^{-1}\right)$ after being inoculated by drip $\left(9.2 \log\right.$ CFU. $\left.\mathrm{mL}^{-1}\right)$ [20].

\subsection{Thermal and chemical treatments}

Treatment of açai berries by blanching at $90{ }^{\circ} \mathrm{C}$ for $10 \mathrm{~s}$ showed the highest efficiency in reducing the microbial load of açai berries contaminated with strains of E.coli $\left(3.0 \pm 0.8 \log\right.$ CFU.mL $\left.{ }^{-1}\right)$ than all other treatments (Table 
2). However, when the berries were infected with Salmonella spp., blanching at $90{ }^{\circ} \mathrm{C}$ for $10 \mathrm{~s}(2.6 \pm 0.8 \log$ CFU. $\left.\mathrm{mL}^{-1}\right)$ obtained greater cell reduction only in relation to single washing with distilled water $(0.8 \pm 0.7 \mathrm{log}$ CFU. $\left.\mathrm{mL}^{-1}\right)$. Reductions in microbial load of Salmonella spp. when the berries were blanched at $90{ }^{\circ} \mathrm{C}(2.6 \pm 0.8$ $\log$ CFU.mL $\left.{ }^{-1}\right)$ and $80^{\circ} \mathrm{C}\left(2.0 \pm 0.2 \log\right.$ CFU.mL $\left.{ }^{-1}\right)$ for $10 \mathrm{~s}$ were statistically similar. The use of blanching at 80 ${ }^{\circ} \mathrm{C}$ for $10 \mathrm{~s}\left(2.6 \pm 0.8 \log\right.$ CFU.mL $\left.{ }^{-1}\right)$ on berries inoculated with Salmonella spp. and E. coli showed the same efficacy in microbial reductions after washing with ozonated water at $4 \mathrm{mg} \mathrm{mL}^{-1}$ for $5 \mathrm{~min}$, washing with chlorinated water at $200 \mathrm{mg} \cdot \mathrm{mL}^{-1}$ and single washing with distilled water (Table 2).

Raising the blanching temperature $\left(80^{\circ} \mathrm{C}\right.$ to $90{ }^{\circ} \mathrm{C}$ ) (Table 2) should cause a greater reduction of the number of microorganisms. Indeed, this would theoretically increase the lethal ratio (L) 10-fold [21]. In testing E. coli, there was a significant reduction $(p<0.05)$ of microbial load when the blanching temperature increased (Table 2). In one study testing several blanching temperatures for the period of $10 \mathrm{~s}$, the authors observed a discrete logarithmic reduction, but not significant, in mesophilic bacteria when raising the blanching temperature from $80{ }^{\circ} \mathrm{C}$ to $90{ }^{\circ} \mathrm{C}$ and $100{ }^{\circ} \mathrm{C}[19]$. In another study, blanching of bean sprouts was more effective in reducing Salmonella spp., and E. coli compared to washing with distilled and ozonated water [9].

The ozonated washing at concentrations of $4 \mathrm{mg} \mathrm{mL}^{-1} \mathrm{O}_{3}$ for $5 \mathrm{~min}$ did not result in a significant reduction in the cell counts of $E$. coli $\left(0.6 \pm 0.1 \log\right.$ CFU.mL $\left.{ }^{-1}\right)$ when compared to blanching at $80^{\circ} \mathrm{C}$ for $10 \mathrm{~s}(1.1 \pm 0.6 \mathrm{log}$ CFU.mL $\left.{ }^{-1}\right)$ or washing in $200 \mathrm{mg} \cdot \mathrm{mL}^{-1}$ chlorinated water $\left(0.9 \pm 0.1 \log\right.$ CFU.mL $\left.{ }^{-1}\right)$ or distilled water $(0.5 \pm 0.2$ $\log$ CFU.mL $\mathrm{mL}^{-1}$ ) (Table 2). Treatment of blueberries with aqueous ozone at a concentration of $3.7 \mathrm{mg} \cdot \mathrm{mL}^{-1}$ for 8 min caused a reduction of $0.1 \pm 1.50 \log$ CFU.g ${ }^{-1}$ in E. coli O157: $\mathrm{H} 7$ and $2.40 \pm 0.10 \log \mathrm{UFC}^{-g^{-1}}$ in Salmonella spp. [22]. These different results for the efficacy of ozonation from artificially inoculated microorganisms can be explained by various factors, such as the different plants studied, the test organism used, the physiological state of microbial cells and the ozone release method [14].

Chlorination of berries at a concentration of $200 \mathrm{mg} \cdot \mathrm{L}^{-1}$ did not perform better than any other treatment, including mere washing with water, for all test microorganisms (Table 2). The reductions of the microbial loads of Salmonella spp. $\left(1.5 \pm 0.3 \log\right.$ CFU.mL $\left.{ }^{-1}\right)$ and E. coli $\left(0.9 \pm 0.1 \log\right.$ CFU.mL $\left.{ }^{-1}\right)$ when washed with chlorinated water $\left(200 \mathrm{mg} \cdot \mathrm{L}^{-1}\right)$ were similar to those found on tomatoes treated with the same concentration of chlorine for 5 min [17]. The variety of results from these and other published studies of the effectiveness of chlorination for vegetable and fruit sanitizing is related to factors such as chlorine concentration applied, $\mathrm{pH}$ and immersion time. Some authors have found typical microbial reductions of $<2 \log [23]$ and depending on the test microorganism combined with these factors, reductions can be achieved of $<1$ to $3.15 \log$ CFU.g ${ }^{-1}$ [24].

The reduced effectiveness in lowering the number of microbial cells observed in trials involving thermal and non-thermal treatments applied to açai berries may be due to microbial cell infiltration into deeper fruit layers. Human pathogenic microorganisms can infiltrate the fruit through injuries and cracks of the cuticle and epidermal tissues, preventing the action of sanitizers applied to the surface [25]. The açai berry has a pulpy epicarp that is about $1 \mathrm{~mm}$ thick, enveloping a voluminous and hard endocarp and seed, and an abundant marbled endosperm [3]. This thin pulp is only $5-15 \%$ of the total fruit volume [19] and is very fragile, so it can be broken by simple friction, allowing entry of pathogens during harvest, transport and processing. The infiltration process in fruits and vegetables depends on temperature, time and atmospheric pressure. It is promoted when the water pressure on the product surface becomes higher than the internal pressure of the tissues. The pathogens can establish colonies that are extremely difficult to reach by aqueous chemical solutions [25]. Infiltration studies have been performed on tomatoes [26] and apples [27] involving Salmonella spp. and E. coli, reporting reduced efficacy of sanitizer treatments. The effectiveness of decontamination can be reduced due to infiltration, as in the case of lower E. coli elimination in apples treated with chlorinated solutions [27].

\subsection{Thermal treatments $\left(90{ }^{\circ} \mathrm{C}\right)$ and cooling}

Cooling of the açai berries with water after heat treatment may be a source of microbiological recontamination [28], mainly if the water used is unclean. Moreover, during the cooling process, pathogenic microorganisms can withdraw into the fruit [25]. Several sources of water were investigated for berry cooling after blanching at 90 ${ }^{\circ} \mathrm{C}$ to observe the effects on sanitizing performance (Figure 3). Heat treatment at $90{ }^{\circ} \mathrm{C}$ combined with cooling in previously sanitized water produced a more pronounced average logarithmic reduction of Salmonella spp. load in relation to simple blanching at $90{ }^{\circ} \mathrm{C}$, although not in relation to the combination of blanching and ozonation (Figure 3). Cooling with chlorinated water at concentrations of $50 \mathrm{mg} . \mathrm{L}^{-1}$ and $200 \mathrm{mg} . \mathrm{L}^{-1}$ after led to greater reduction of Salmonella spp., but did not differ from cooling with tap water. Cooling with water with the two ozone concentrations ( 3 and $4 \mathrm{mg} \cdot \mathrm{L}^{-1}$ ) performed worse and did not differ from each other in the logarithmic reduction of Salmonella spp. Regarding the berries contaminated with E. coli and heat treated at 90 ${ }^{\circ} \mathrm{C}$, the different sources of water used for cooling the berries showed no significant difference in reducing the initial population (Figure 4). E. coli load reductions observed in the combined treatments were lower than those found when the blanching at $90{ }^{\circ} \mathrm{C}$ was applied with distilled water (Table 2).In one study, combining technologies (hurdle method) was found to improve log reduction [23], while in another the treatments had 
antagonistic effects and consequently a hurdle effect was not observed [12]. In our study, the combination of blanching at $90{ }^{\circ} \mathrm{C}$ with subsequent cooling with chlorinated water resulted in synergistic effect for the logarithmic reduction of Salmonella spp., because the values were higher than those found when the berries were blanched and cooled with distilled water. But cooling with ozonated water at any concentration did not show this increased effect for Salmonella spp. and could even be considered to have an antagonistic effect because the values were below the average for blanching to $90{ }^{\circ} \mathrm{C}$ with cooling in distilled water. The indiscriminate action of ozone on bacteria and organic matter can explain the reduced effectiveness of ozone treatments in both assays compared to simple washing with water, because cuts on fruit surface promote the lixiviation of organic matter, which can react with ozone before acting on the bacteria adhered on the fruit surface [23]. Other authors considered that aqueous ozone when applied in açai fruit did not affect the sensory quality of its beverage enough to be discriminated by consumers [29]. Moreover, some studies show that ozone was significantly effective in reducing dislodged microorganisms in wash water, but had limited impact on bacteria attached to produce surfaces $[20,30]$.

\section{FIGURES AND TABLES}

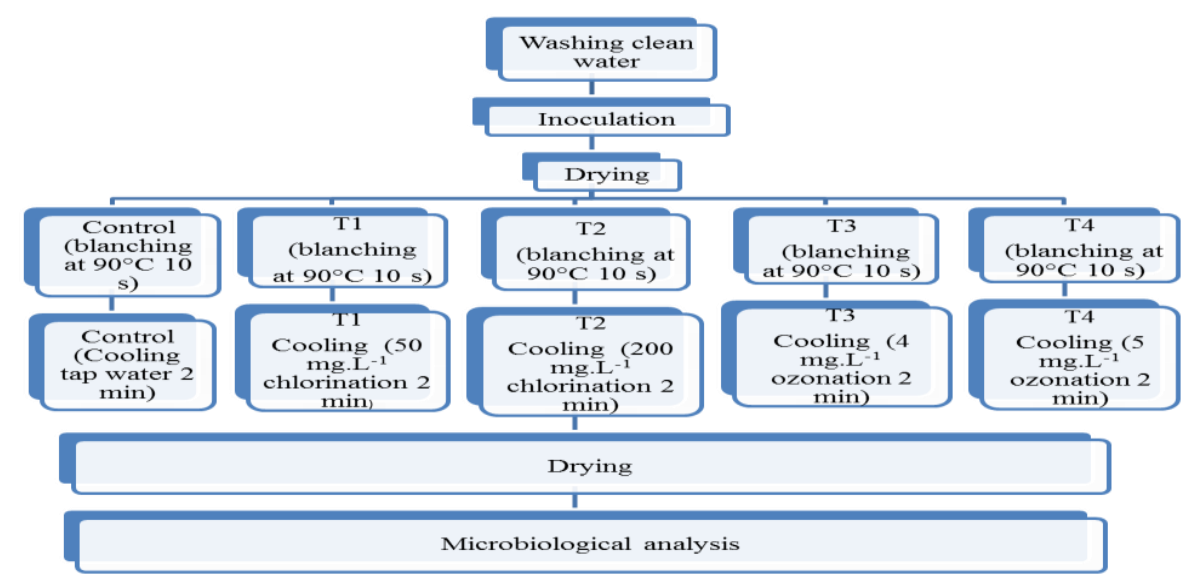

Figure 1. Flow diagram with thermal (blanchings at $80^{\circ} \mathrm{C}$ and $90{ }^{\circ} \mathrm{C}$ ) and non-thermal (chlorination and ozonation)) treatments used to sanitization of açai berries

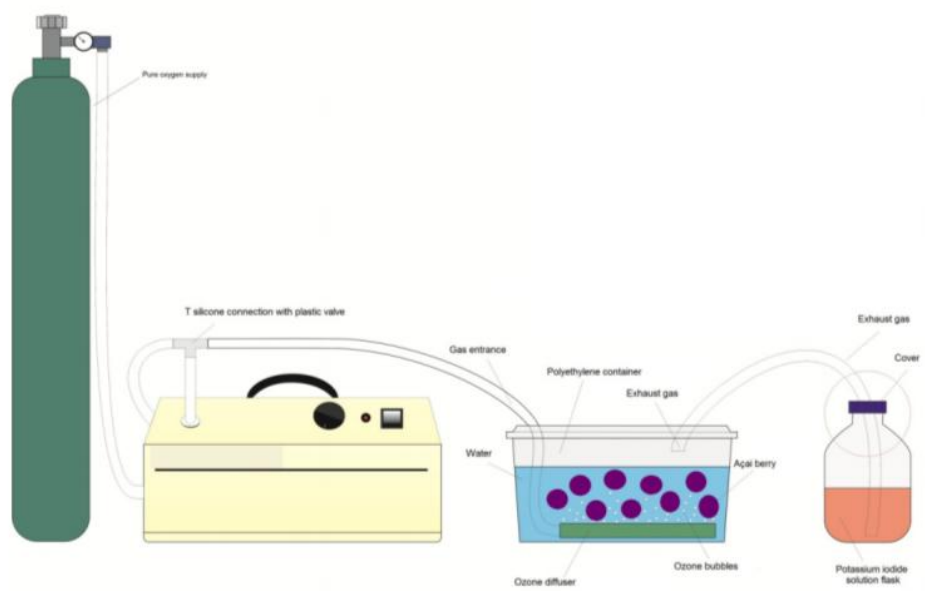

Figure 2. Aqueous ozonation scheme of açai berries 


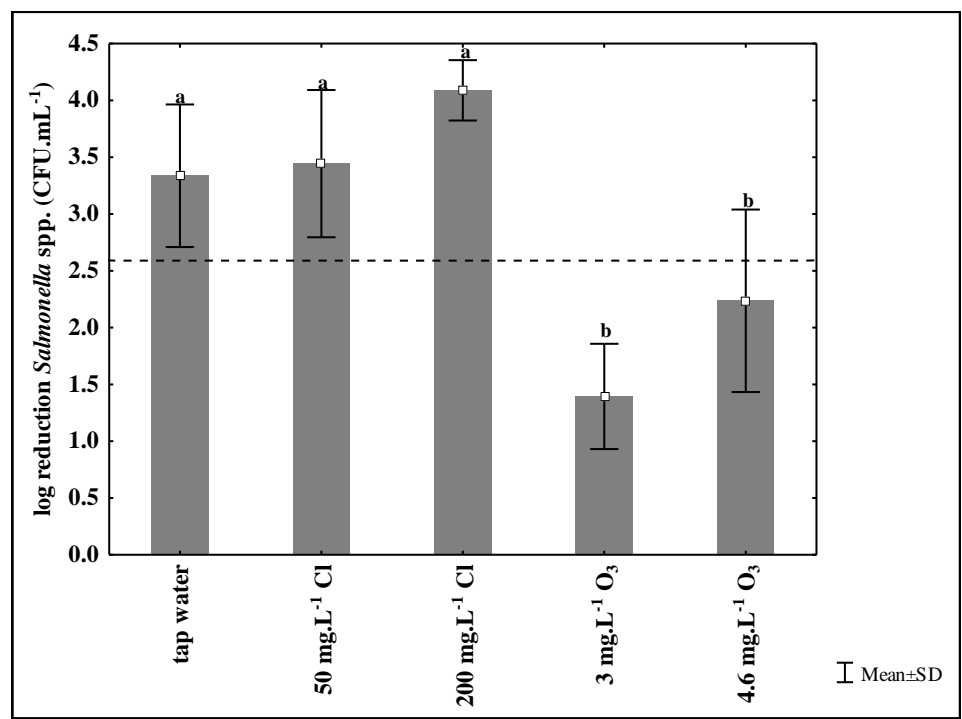

Figure 3. Log reduction of inoculated Salmonella spp. in açai berries treated by blanching at $90{ }^{\circ} \mathrm{C}$ and cooled at different sources of water. Dotted line represents $\log$ reduction of blanching $90{ }^{\circ} \mathrm{C}$

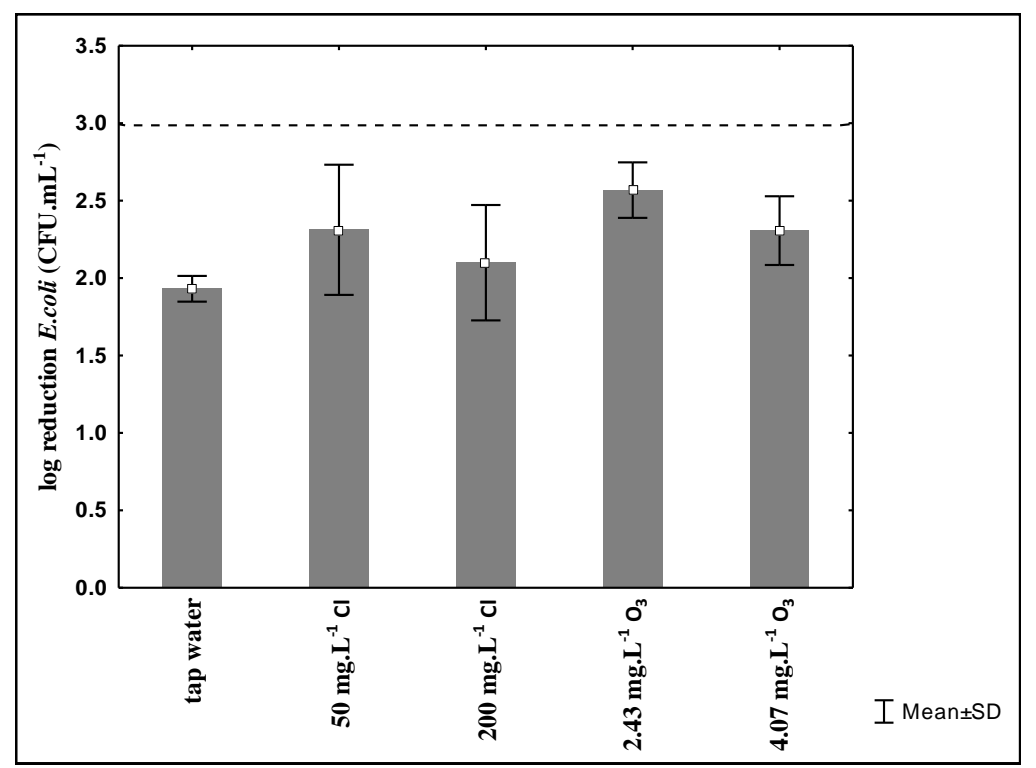

Figure 4. Log reduction of inoculated E. coli in açai berries treated by blanching at $90{ }^{\circ} \mathrm{C}$ and cooled at different sources of water. Dotted line represents log reduction of blanching $90{ }^{\circ} \mathrm{C}$

Table 1 - Inoculum suspension concentration $\left(\log \mathrm{CFU} \cdot \mathrm{mL}^{-1}\right)$ and enumeration of test microorganisms recovered from açai berries inoculated by drip at assay \#1 (thermal and chemical treatments) and assay \#2 (blanching at $90^{\circ} \mathrm{C}$ and cooling)

\begin{tabular}{|l|c|c|c|c|}
\hline Test microorganism & \multicolumn{2}{|c|}{$\left.\begin{array}{c}\text { Inoculum suspension } \\
(\log \text { CFU.mL }\end{array}\right)^{\mathbf{a}}$} & \multicolumn{2}{c|}{$\left.\begin{array}{c}\text { Recovery in açai berries } \\
(\log \text { CFU.mL }\end{array}\right)^{\mathbf{a}}$} \\
& \multicolumn{2}{|c|}{ Assay \#1 Assay \#2 } & \multicolumn{2}{|c|}{ Assay \#1 Assay \#2 } \\
\hline Salmonella spp. & 9.4 & 9.3 & 8.2 & 7.2 \\
\hline E.coli & 9.6 & 9.3 & 8.2 & 7.7 \\
\hline
\end{tabular}

${ }^{\text {a }}$ Values represent the mean of three replicates. 
Table 2. Logarithmic reduction (log CFU. $\mathrm{mL}^{-1}$ ) relative to thermal and non-thermal treatments in açai berries inoculated with test microorganisms

\begin{tabular}{|l|c|c|}
\hline Treatment & $\begin{array}{c}\text { Salmonella spp. } \\
\boldsymbol{p = 0 . 0 4 0 1 2}\end{array}$ & $\begin{array}{c}\text { E. coli } \\
\boldsymbol{p = 0 . 0 0 0 0 9}\end{array}$ \\
\hline Blanching at $90{ }^{\circ} \mathrm{C} 10 \mathrm{~s}$ & $2.6 \pm 0.8 \mathrm{a}$ & $3.0 \pm 0.8 \mathrm{a}$ \\
\hline Blanching at $80{ }^{\circ} \mathrm{C} 10 \mathrm{~s}$ & $2.0 \pm 0.2 \mathrm{ab}$ & $1.1 \pm 0.6 \mathrm{~b}$ \\
\hline Ozonated water $\left(4 \mathrm{mg} . \mathrm{L}^{-1}\right) 5 \mathrm{~min}$ & $1.6 \pm 0.1 \mathrm{ab}$ & $0.6 \pm 0.1 \mathrm{~b}$ \\
\hline Chlorinated water $\left(200 \mathrm{mg} \cdot \mathrm{L}^{-1}\right) 15 \mathrm{~min}$ & $1.5 \pm 0.3 \mathrm{ab}$ & $0.9 \pm 0.1 \mathrm{~b}$ \\
\hline Distilled water $15 \mathrm{~min}$ & $1.2 \pm 0.1 \mathrm{~b}$ & $0.5 \pm 0.2 \mathrm{~b}$ \\
\hline
\end{tabular}

Values in the same column with different letter are significantly different $(p<0.05)$.

\section{CONCLUSION}

The thermal treatment of açai berries in water at $90{ }^{\circ} \mathrm{C}$ for a period of $10 \mathrm{~s}$ is was most effective in reducing contamination of the pathogenic microorganisms studied, mainly E. coli, but it should be combined with cooling with water containing some type of sanitizer capable of destroying any pathogenic microorganisms present, and consequently preventing infiltration of the berry. It is important to consider that the pathogens studied showed a high rate of survival, regardless of the treatment. Thus, the microbiological safety of açai berries depends fundamentally on the prevention of contamination. Future studies will be conducted of combining blanching treatment with cooling in chlorinated and ozonated water to sanitize açai, as well as the nutritional value and sensory properties of the açai berries.

\section{Acknowledgements}

This research project has financial support from the government of the state of Amapá, Brazil, through the State Secretariat of Science and Technology - SETEC and the Amapá State Research Foundation. Support was also provided by Embrapa Food Technology and the Carlos Chagas Filho Foundation for Support of Research in the State of Rio de Janeiro (FAPERJ - Ref. Number E 202.863/2015).

\section{REFERENCES}

[1] M.A Pavan, S. J. Schmidt and H. Feng, Water sorption behavior and thermal analysis of freeze-dried, Refractance Window-dried and hot-air dried açaí (Euterpe oleracea Martius) juice, LWT - Food Science and Technology, 2012; 48: 75-81.

[2] Ministério da Saúde (MS), 2008. Água Brasil, Região Norte: municípios com simples desinfecção cloração no ano de 2008. Available at: http://www.aguabrasil.icict.fiocruz.br/index.php?pag=c_r_i.

[3] M.S.P. Oliveira, J.T. Farias Neto, and R.S. Pena, Açaí: técnicas de cultivo e processamento (Instituto Frutal, 104 pp, 2007).

[4] F. Aguiar, V. Menezes, and H. Rogez, Spontaneous postharvest fermentation of açaí (Euterpe oleracea) fruit, Postharvest Biology Technology, 2013; 86: 294-299.

[5] Governo do Estado do Pará, 2012. Decreto n³26, de 20 janeiro de 2012. Available at: http://www.sagri.pa.gov.br/files/pdfs/D E C R E T O N 326-2012.pdf.

[6] K.S. Pereira, F.L. Schmidt, A. M Guaraldo, R.M.B. Franco, V. L. Dias and L.C. Passos, Chagas disease as a foodborne illness, Journal of Food Protection, 2009; 42: 441-446.

[7] H. Rogez, J.N.S Souza, M.Q. Nascimento and R. Buxant, Branqueamento dos frutos de açaí (Euterpe oleracea Mart.) para a diminuição da carga microbiana do suco, Associação Brasileira de Química, 1996; 45: $177-184$.

[8] C. Phungamngoen, N. Chiewchan and S. Devahastin, Effects of various pretreatments and drying methods on Salmonella resistance and physical properties of cabbage, Journal of Food Engineering, 2013; 115: 237-244.

[9] L.K. Phua, S.Y. Neo, G.H. Khoo and H.G. Yuk, Comparison of the efficacy of various sanitizers and hot water treatment in inactivating inoculated foodborne pathogens and natural microflora on mung bean sprouts, Food Control, 2014; 42: 270-276.

[10] G.R. Dychdala, Chlorine and chlorine compounds, in Block, S. S. (ed.) Disinfection, sterilization, and preservation, (Ed. Philadelphia, 1991) 131-151.

[11] S. Ruiz-Cruz, E. Acedo-Félix, M. Díaz-Cinco, M.A. Islas-Osuna and G.A. González-Aguilar, Efficacy of sanitizers in reducing Escherichia coli O157:H7, Salmonella spp. and Listeria monocytogenes populations on fresh-cut carrots, Food Control, 2007; 18: 1383-1390. 
[12] E.M.C. Alexandre, D.M. Santos-Pedro, T.R.S. Brandão and C.L.M Silva, Influence of aqueous ozone, blanching and combined treatments on microbial load of red bell peppers, strawberries and watercress, Journal of Food Engineering, 2011; 105: 277-282.

[13] United States Environmental Protection Agency (USEPA), 1999. EPA Guidance Manual - Alternative Disinfectants and Oxidants. Available at: http://www.epa.gov/ogwdw/mdbp/alternative_disinfectants_guidance.pdf.

[14] H. Ölmez and M.Y. Akbas, Optimization of ozone treatment of fresh-cut green leaf lettuce, Journal of Food Engineering, 2009; 90: 487-494.

[15] C.C.S. Coelho, O. Freitas-Silva, R.S. Campos, V.S. Bezerra and L.M.C. Cabral, Ozonização como tecnologia pós-colheita na conservação de frutas e hortaliças: Uma revisão, Revista Brasileira de Engenharia Agrícola e Ambiental, 2015; 19: 369-375.

[16] K. Sethy, Antimicrobial activity of thermotolerant bacterial isolate from coal mine spoil, African Journal of Microbiology Research, 2012; 6: 5459-5463.

[17] M.M. Lang, L.J. Harris and L.R. Beuchat, Survival and recovery of Escherichia coli O157:H7, Salmonella, and Listeria monocytogenes on lettuce and parsley as affected by method of inoculation, time between inoculation and analysis, and treatment with chlorinated water, Journal of Food Protection, 2004; 67: 1092-1103.

[18] APHA, AWWA, and WEF, Standard Methods for the Examination of Water and Wastewater ( Eds., 21st ed, 2005, $541 \mathrm{pp}$ ).

[19] H. Rogez, Açaí: preparo, composição e melhoramento da conservação (Edufpa, 2000).

[20] Long III, W. Pao, S. Inserra, P. Westbrook, and S. Ahn, Efficacy of ozone produce washers in reducing natural and artificially inoculated microorganisms on roma tomatoes and green onions, Journal of Food Safety, 2011; 31: 268-275.

[21] J. E. Gaze, Pasteurisation: a food industry practical guide, Guideline 51., (2nd ed. Chipping Campden, 2006).

[22] K.L. Bialka, A. Demirci and V.M. Puri, Modeling the inactivation of Escherichia coli O157:H7 and Salmonella enterica on raspberries and strawberries resulting from exposure to ozone or pulsed UV-light, Journal of Food Engineering, 2008; 85: 444-449.

[23] C. Goodburn and C. Wallace, The microbiological efficacy of decontamination methodologies for fresh produce: A review, Food Control, 2013; 32: 418-42.

[24] B. Ramos, F. Miller, T.R.S. Brandão, P. Teixeira and C.L.M. Silva, Fresh fruits and vegetables - An overview on applied methodologies to improve its quality and safety, Innovative Food Science and Emerging Technologies, 2013; 20:1-15.

[25] L.R. Beuchat and D.A. Mann, Factors affecting infiltration and survival of Salmonella on in-shell pecans and pecan nutmeats, Journal of Food Protection, 2010; 73: 1257-1268.

[26] [26] X. Guo, J. Chen, R.E. Brackett and L.R. Beuchat, Survival of Salmonella on and in Tomato Plants from the Time of Inoculation at Flowering and Early Stages of Fruit Development through Fruit Ripening, Applied and Environmental Microbiology, 2001; 67: 4760-4764.

[27] S.J. Kenney and L.R. Beuchat, Comparison of aqueous commercial cleaners for effectiveness in removing Escherichia coli O157:H7 and Salmonella muenchen from the surface of apples, International Journal of Food Microbiology, 2002; 74: 47-55.

[28] S. Van Haute, I. Tryland, A. Veys and I. Sampers, Wash water disinfection of a full-scale leafy vegetables washing process with hydrogen peroxide and the use of a commercial metal ion mixture to improve disinfection efficiency, Food Control, 2015; 50: 173-183.

[29] V.S. Bezerra, O. Freitas-Silva, L.F. Damasceno, A.M.G.N. Mamede and L.M.C. Cabral, Sensory Analysis and Consumers Studies of Açai Beverage after Thermal, Chlorine and Ozone Treatments of the Fruits, Journal of Food Processing and Preservation. doi: 10.1111/jfpp.12961, 2016.

[30] O. Freitas-Silva and Souza A.M. Ozone in Food Processing: Impact on Food Products Attributes. In: Amit K. Jaiswal (Ed.). Food Processing Technologies: Impact on Product Attributes. Boca Raton: CRC Press, 2016. Ch. 18, p. 519-545. ISBN 9781482257540. 